\title{
PKCa Deficiency in Mice Is Associated with Pulmonary Vascular Hyperresponsiveness to Thromboxane A2 and Increased Thromboxane Receptor Expression
}

\author{
Christoph Tabeling ${ }^{\text {a }}$ Elena Noe $^{\text {a Jan Naujoks }}{ }^{\text {a Jan-Moritz Doehn }}{ }^{\mathrm{a}}$ \\ Stefan Hippenstiel ${ }^{\mathrm{a}}$ Bastian Opitz ${ }^{\mathrm{a}}$ Norbert Suttorp ${ }^{\mathrm{a}}$ Robert Klopfleisch ${ }^{\mathrm{b}}$ \\ Martin Witzenrath ${ }^{a}$ \\ a Department of Infectious Diseases and Pulmonary Medicine, Charité - Universitätsmedizin Berlin, and \\ ${ }^{b}$ Department of Veterinary Pathology, College of Veterinary Medicine, Freie Universität Berlin, Berlin, Germany
}

\section{Key Words}

Pulmonary vascular responsiveness $\cdot$ Hypoxic pulmonary vasoconstriction - Pulmonary arterial hypertension .

Protein kinase $\mathrm{C}$ iota

\begin{abstract}
Pulmonary vascular hyperresponsiveness is a main characteristic of pulmonary arterial hypertension (PAH). In PAH patients, elevated levels of the vasoconstrictors thromboxane A2 (TXA2), endothelin (ET)-1 and serotonin further contribute to pulmonary hypertension. Protein kinase $C$ (PKC) isozyme alpha (PKCa) is a known modulator of smooth muscle cell contraction. However, the effects of PKCa deficiency on pulmonary vasoconstriction have not yet been investigated. Thus, the role of PKCa in pulmonary vascular responsiveness to the TXA2 analog U46619, ET-1, serotonin and acute hypoxia was investigated in isolated lungs of $\mathrm{PKCa}^{-/-}$mice and corresponding wild-type mice, with or without prior administration of the PKC inhibitor bisindolylmaleimide I or
\end{abstract}

Gö6976. mRNA was quantified from microdissected intrapulmonary arteries. We found that broad-spectrum PKC inhibition reduced pulmonary vascular responsiveness to ET-1 and acute hypoxia and, by trend, to U46619. Analogously, selective inhibition of conventional PKC isozymes or PKCa deficiency reduced ET-1-evoked pulmonary vasoconstriction. The pulmonary vasopressor response to serotonin was unaffected by either broad PKC inhibition or PKCa deficiency. Surprisingly, $\mathrm{PKCa}^{-/-}$mice showed pulmonary vascular hyperresponsiveness to $U 46619$ and increased TXA2 receptor (TP receptor) expression in the intrapulmonary arteries. To conclude, PKCa regulates ET-1-induced pulmonary vasoconstriction. However, PKCa deficiency leads to pulmonary vascular hyperresponsiveness to TXA2, possibly via increased pulmonary arterial TP receptor expression.

(c) 2016 S. Karger AG, Basel

Christoph Tabeling and Elena Noe contributed equally to this work. The study is part of the PhD thesis of Elena Noe.

\section{KARGER 125}

(c) 2016 S. Karger AG, Base

$1018-1172 / 16 / 0524-0279 \$ 39.50 / 0$

E-Mail karger@karger.com

www.karger.com/jvr
Prof. Dr. Martin Witzenrath

Department of Infectious Diseases and Pulmonary Medicine

Charité - Universitätsmedizin Berlin, Charitéplatz 1

DE-10117 Berlin (Germany)

E-Mail Martin.Witzenrath@ charite.de 


\section{Introduction}

Pulmonary arterial hypertension $(\mathrm{PAH})$ is a fatal condition. Increased pulmonary vasoconstriction and progressive remodeling of the pulmonary arteries lead to elevated pulmonary arterial resistance and ultimately to right heart failure. Endothelial dysfunction, characterized by an imbalance between vasoconstrictive and vasodilative mediators, is an important feature of $\mathrm{PAH}$ pathobiology [1]. In PAH patients, increased levels of thromboxane A2 (TXA2) [2], endothelin (ET)-1 [3] and serotonin [4] as well as decreased levels of nitric oxide [5] and prostacyclin [2] have been observed. Moreover, the pulmonary vasopressor response to constrictive agents is enhanced in PAH patients [6], reflecting a hypercontractile state of pulmonary vascular smooth muscle cells. This hyperresponsiveness is believed to potentiate pulmonary vasoconstriction induced by the imbalance of the vasoactive agents.

In patients with systemic sclerosis-associated $\mathrm{PAH}$, functional autoantibodies against the ET receptor A and/ or the angiotensin II receptor type 1 may contribute to increased pulmonary vasoconstriction [7]. Pulmonary vascular hyperresponsiveness is also a key feature of commonly used experimental models of $\mathrm{PAH}$ including the monocrotaline [8], the T-helper (Th)2 inflammation [9, 10] and the hypoxia model [11], and it has been reported for clinically relevant vasoconstrictors like TXA2, ET-1, serotonin and alveolar hypoxia $[8,9]$. Mechanistically, pulmonary vascular hyperresponsiveness has been proposed to be partially dependent on protein kinase $\mathrm{C}$ (PKC) signaling [9].

$\mathrm{PKC}$ is a family of serine/threonine kinases, which are classified into conventional (c)PKC, novel (n)PKC and atypical (a)PKC isozymes $[12,13]$. Both conventional ( $\alpha$, $\beta_{\mathrm{I}}, \beta_{\mathrm{II}}$ and $\left.\gamma\right)$ and novel PKC isozymes $(\delta, \varepsilon, \eta$ and $\theta)$ require phospholipids and 1,2-diacylglycerol for activation, whereas activation of the conventional isoforms additionally depends on $\mathrm{Ca}^{2+}[13]$. Atypical isozymes $(\zeta, \mathrm{l} / \lambda)$ also require phospholipids but are activated independently of 1,2-diacylglycerol and $\mathrm{Ca}^{2+}$ [13].

Isozymes $\alpha, \beta, \delta, \varepsilon$ and $\zeta$ have been implicated in smooth muscle cell contraction via myosin light-chain phosphorylation, $\mathrm{Ca}^{2+}$ channel activation and/or $\mathrm{K}^{+}$ channel inhibition [13], and PKC has been proposed as a therapeutic target in pulmonary (arterial) hypertension $[12,14]$. Nevertheless, PKC isozymes are differentially expressed and opposing effects of separate isozymes have been described $[12,15]$, highlighting the potential need for isozyme-specific targeting.
Hitherto, little is known about the functional role of specific PKC isozymes in the pulmonary vasculature [14]. Cogolludo et al. [16] reported the involvement of PKC $\zeta$ in TXA2-evoked pulmonary arterial constriction, whereas PKCe has been shown to specifically modulate hypoxic pulmonary vasoconstriction (HPV) [17], which has previously been reported to be PKC-dependent [18]. Diminishing effects on HPV following broad-spectrum PKC inhibition have been repeatedly described [18-20], but cPKC isozymes do not seem to play a role in mediating HPV [20]. Snow et al. [21] found that intermittent hypoxia augments ET-1-induced pulmonary vasoreactivity in a $\mathrm{PKC} \beta$-dependent manner, and it has been suggested that $\mathrm{PKC} \delta$ plays a role in modulating contraction in pulmonary arterial smooth muscle cells (PASMCs) due to angiotensin II [22]. Moreover, PKC is thought to promote ET-1-induced contraction of human pulmonary arteries [23], possibly via the mediation of ET-1-induced inhibition of $\mathrm{K}_{\mathrm{v}}$ channels, which has been shown to be PKC-dependent [23]. However, the functional role of the specific isozyme PKCa in the pulmonary vasculature remains elusive.

TXA2, ET-1 and serotonin mediate pulmonary vasoconstriction via direct $G$ protein-coupled receptor activation on vascular smooth muscle cells. Hypoxia-induced contraction of isolated PASMCs or pulmonary artery rings requires intrinsic mechanisms including hypoxia sensing and signal transduction [24]. Alternatively, HPV in the intact lung involves hypoxia sensing at the alveolocapillary level, from where the signal is conducted retrogradely to the upstream pulmonary arterioles where it is transferred to PASMCs which ultimately contract [25]. PKC-dependent vasoconstriction has been described for each of these vasoconstrictive stimuli $[16,18-21,26-29]$. Nevertheless, the role of PKC in TXA2- and serotonin-evoked pulmonary vascular responsiveness is controversial, since species- and compound-related differences have been observed $[16,18$, $26,27]$.

In this study, we dissected the role of PKCa in pulmonary vascular responsiveness to the $\mathrm{PAH}$-associated vasoconstrictors TXA2, ET-1, serotonin and alveolar hypoxia, by investigating isolated perfused lungs of $\mathrm{PKCa}-$ deficient $\left(\mathrm{PKCa}^{-/-}\right)$mice. In order to compare the $\mathrm{PKC} \alpha$-specific effects to the overall PKC or CPKC signaling effects, broad-spectrum PKC inhibition and inhibition of the conventional PKC isozymes, PKC $\alpha$ and $\mathrm{PKC} \beta$, was studied in parallel. 


\section{Materials and Methods}

Mice

All experiments were approved by the local Department of Health and Social Affairs (Landesamt für Gesundheit und Soziales, LAGeSo, Berlin, Germany). Female $\mathrm{PKCa}^{-/-}$and corresponding wild-type (WT) mice (8-11 weeks old) on a 129 SV background were used for all experiments. The generation of $\mathrm{PKCa}^{-/-}$mice has been described elsewhere [30]. The WT mice were purchased from Charles River Laboratories (Sulzfeld, Germany). All mice were housed in individually ventilated cages inside a climate- and lightcycle-controlled animal house, and were fed a diet of standard chow and tap water ad libitum.

\section{Isolated Perfused and Ventilated Mouse Lungs}

Mouse lungs were isolated as described previously [31,32]. Briefly, mice were anesthetized i.p. with $160 \mathrm{mg}$ ketamine and $75 \mathrm{mg}$ xylazin per kilogram of body weight, tracheally intubated, ventilated and then heparinized by intracardial injection of 125 IU of heparin sodium and exsanguinated. The pulmonary artery and the left atrium were cannulated in order to perfuse the lung vasculature with sterile and carbonated $(20 \mathrm{mmol} / \mathrm{l} \mathrm{NaHCO} 3) 37^{\circ} \mathrm{C}$ Krebs-Henseleit hydroxyethylamylopectin buffer $(1 \mathrm{ml} / \mathrm{min}$; Serag-Wiessner, Naila, Germany). Left atrial pressure was set at $+2.2 \mathrm{~cm} \mathrm{H}_{2} \mathrm{O}$. Lungs were ventilated with negative pressure in a closed chamber (expiratory pressure of $-4.5 \mathrm{~cm} \mathrm{H}_{2} \mathrm{O}$; inspiratory pressure of $-9.0 \mathrm{~cm} \mathrm{H}_{2} \mathrm{O}$; 90 breaths/min) and hyperinflation $\left(-24 \mathrm{~cm} \mathrm{H}_{2} \mathrm{O}\right)$ was performed at 4-min intervals. All hardware and software were purchased from HSE-Harvard Apparatus (March-Hugstetten, Germany). Mean pulmonary arterial pressure (Ppa mean) and airway resistance were continuously monitored. Data were discarded from further analyses if lungs had signs of hemostasis, atelectasis or edema.

\section{Pulmonary Vascular Responsiveness}

To study the effects of PKC inhibition, broad-spectrum PKC inhibitor bisindolylmaleimide I (BIM, $1 \mu \mathrm{mol} / \mathrm{l}$; Santa Cruz Biotechnologies, Santa Cruz, Calif., USA), the selective inhibitor of the conventional PKC isozymes PKCa and PKC $\beta$ Gö6976 (1 $\mu \mathrm{mol} / \mathrm{l}$; Merck Millipore, Darmstadt, Germany) or solvent (DMSO <1\%o) was added to the perfusate. After a steady-state period of approximately $12 \mathrm{~min}$, increasing doses of ET-1 (10 and $100 \mathrm{nmol} / \mathrm{l}$; Merck Millipore), serotonin (3, 10 and $30 \mu \mathrm{mol} / \mathrm{l}$; Sigma-Aldrich, Steinheim, Germany) or TP receptor agonist U46619 (30, 100 and $300 \mathrm{nmol} / \mathrm{l}$; Merck Millipore) were administered into the perfusion buffer for 10 (ET-1) [9], 0.5 (serotonin) [33] or $3 \mathrm{~min}$ (U46619) [34] each. To investigate the effects of PKCı inhibition on pulmonary vasoconstriction, the $\mathrm{PKCl}$ inhibitor sodium aurothiomalate hydrate (ATM, $20 \mu \mathrm{mol} / \mathrm{l}$; Sigma-Aldrich) was dissolved in the perfusion buffer and the vasopressor response was assessed following a steady-state period of approximately $28 \mathrm{~min}[35,36]$.

For the analysis of HPV, the murine lungs were isolated as described [37], and ventilated with negative pressure in a closed chamber with a tidal volume of approximately $10 \mathrm{ml} / \mathrm{kg}$ body weight and an end-expiratory pressure of $-2 \mathrm{~cm} \mathrm{H} \mathrm{H}_{2} \mathrm{O}$. $\mathrm{HPV}$ and the relationship between pressure $(\mathrm{P})$ and volumetric flow-rate (Q) were analyzed as described before $[38,39]$. Briefly, $\mathrm{N} \omega$-nitroL-arginine methyl ester hydrochloride ( $1 \mathrm{mmol} / \mathrm{l}$; Sigma-Aldrich) and indomethacin $(30 \mu \mathrm{mol} / \mathrm{l}$; Sigma-Aldrich) were added to the perfusate buffer to prevent nitric oxide and prostaglandin synthesis, respectively. After a steady-state period of $10 \mathrm{~min}$, a 4-point pressure-flow (P-Q) curve was generated under normoxic conditions by perfusing the lungs with a flow of $0.5,1,1.5$ or $2 \mathrm{ml} / \mathrm{min}$ for $30 \mathrm{~s}$ each. Perfusion flow was then set at $1 \mathrm{ml} / \mathrm{min}$. After a second steady-state period of $4 \mathrm{~min}$, the Ppa mean was recorded for $12 \mathrm{~min}$ in response to a change from normoxic to hypoxic $\left(1 \% \mathrm{O}_{2}\right)$ ventilation. Approximately 10 minutes after the initiation of $\mathrm{HPV}$, a second P-Q curve was generated.

The difference in Ppa mean ( $\triangle \mathrm{Ppa}$ mean) was expressed as a percentage and the pressure response to the highest stimulus concentration (ET-1, serotonin or U46619), hypoxic ventilation or highest perfusion rate ( $\mathrm{P}-\mathrm{Q}$ curve) of the respective control group was set at $100 \%$.

Representative tracings of the Ppa mean in isolated perfused and ventilated mouse lungs in response to each vasoconstrictive stimulus are shown in online supplementary figure 1 (for all online suppl. material, see www.karger.com/doi/10.1159/000443402).

\section{Microdissection of Intrapulmonary Arteries}

Mouse lungs were isolated and flushed with $\mathrm{NaCl} 0.9 \%$ for $2 \mathrm{~min}$, dissected and instilled with Tissue-Tek ${ }^{\circledR}$ O.C.T.TM ${ }^{\text {TM }}$ compound (Sakura, Staufen, Germany)/PBS (1:4) through the trachea at a pressure of $20 \mathrm{~cm} \mathrm{H}_{2} \mathrm{O}$ for $15 \mathrm{~min}$. Lungs were embedded in Tissue-Tek O.C.T. compound and quick-frozen. Serial $8-\mu \mathrm{m}$-thick cryosections were cut, prepared on membrane slides (membrane slides PEN 1.0, Carl Zeiss, Oberkochen, Germany) and fixated with $-20^{\circ} \mathrm{C}$ ethanol $95 \%$ for $1.5 \mathrm{~min}$. Hematoxylin and eosin staining was performed, followed by dehydration with increasing ethanol concentrations (75, 95 and 100\%). The air-dried membrane slides were used for laser capture microdissection of intrapulmonary arteries with PALM MicroBeam (Carl Zeiss Microimaging GmbH, Bernried, Germany).

\section{Real-Time Quantitative RT-PCR}

Gene expression analysis of microdissected intrapulmonary arteries and whole tissue homogenates of dissected and quick-frozen $\mathrm{PKCa}^{-1-}$ and WT lungs was performed. Total RNA was isolated with silica-membrane technology (NucleoSpin ${ }^{\circledR}$ RNA XS-Kit, Macherey \& Nagel). Reverse transcription was performed using a high-capacity reverse-transcription kit (Applied Biosystems, Darmstadt, Germany). qRT-PCR was achieved with the 7300 realtime PCR system. Glyceraldehyde 3-phosphate dehydrogenase (GAPDH) served as a housekeeping control gene (HKG) while TP receptor and PKC isozymes were genes of interest (GOI). TaqMan $^{\circledR}$ gene expression assays were obtained from Applied Biosystems. The assay IDs were Mm00436917_m1 (TP receptor), Mm00435749_m1 (PKC $\beta), \quad M m 00440861 \_m 1$ (PKC $\left.\gamma\right)$, Mm00440891_m1 (PKC $\delta), \quad M m 00440894 \_m 1 \quad(\mathrm{PKC} \varepsilon)$, Mm01340228_m1 (PKC $), \quad M m 00435769 \_m 1$ (PKCl),

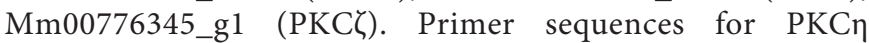
were CgAgggCTgggTggATCT (forward) and gTCTTCgCATAgCCCTTTgg (reverse). WT mice were considered as controls. Relative quantitative gene expression (RQ) was calculated according to the comparative $\mathrm{Ct}$ method: $\Delta \mathrm{Ct}$ : $\mathrm{Ct}_{\mathrm{GOI}}-\mathrm{Ct}_{\mathrm{HKG}} ; \Delta \Delta \mathrm{Ct}$ : $\Delta \mathrm{Ct}_{\mathrm{PKC} \mathrm{A}-\mathrm{I}-\text { or WT }}-\Delta \mathrm{Ct}_{\text {mean WT }}$; RQ: $2^{-\Delta \Delta \mathrm{CT}}$.

\section{Statistical Analysis}

Two-way ANOVA was performed for the comparison of doseresponse curves and the Mann-Whitney $\mathrm{U}$ test for the comparison of data between 2 groups. $\mathrm{p} \leq 0.05$ was considered to be statistically significant and $p$ values are presented as follows: ${ }^{*} p \leq 0.05$, ${ }^{* *} \mathrm{p} \leq 0.01$ and ${ }^{* * *} \mathrm{p} \leq 0.001$. All data are expressed as mean + SEM. 


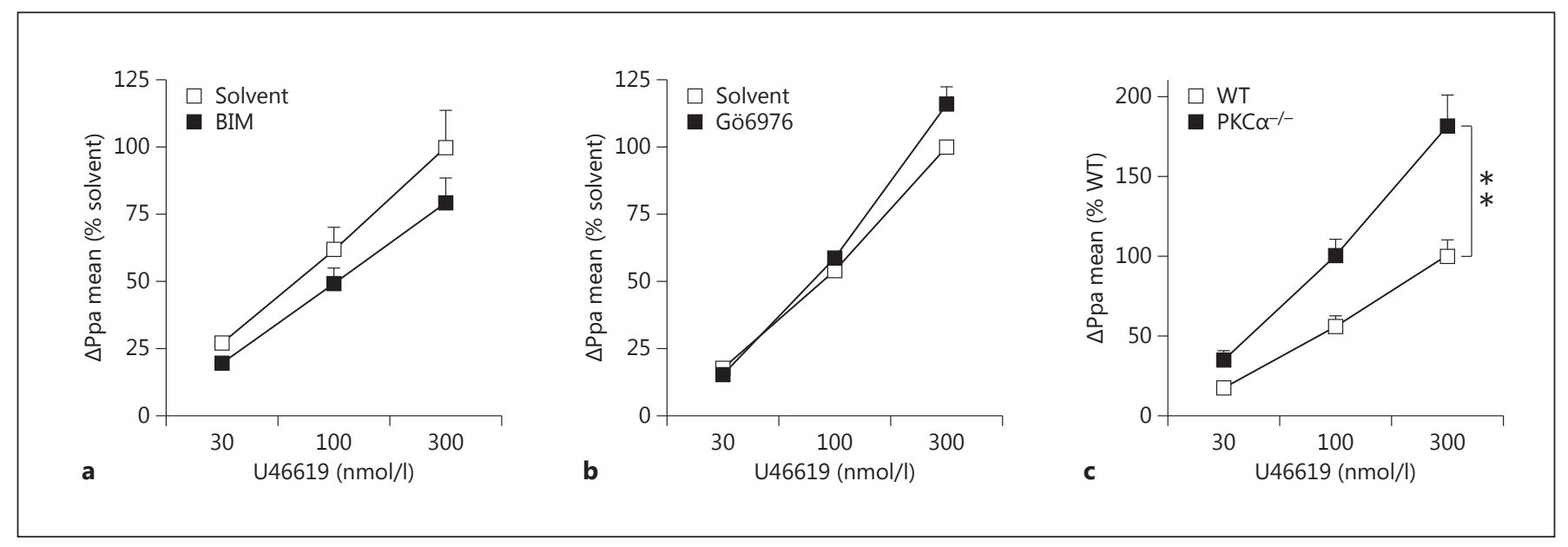

Fig. 1. PKCa deficiency induces pulmonary vascular hyperresponsiveness to TP receptor agonist U46619. a In isolated perfused and ventilated mouse lungs, U46619-evoked pulmonary vasoconstriction was reduced by trend following treatment with the PKC inhibitor BIM $(1 \mu \mathrm{mol} / \mathrm{l})$ compared to solvent treatment. b Selective inhibition of conventional PKC isozymes by Gö6976 (1 $\mu \mathrm{mol} / \mathrm{l})$ had no effect on pulmonary vascular responsiveness to U46619.

\section{Results}

\section{U46619 Caused Pulmonary Vascular}

Hyperresponsiveness in PKC $\alpha$-Deficient Mice

To elucidate the role of PKCa in pulmonary vascular responsiveness, the effects of $\mathrm{PKC}$ inhibition and $\mathrm{PKCa}$ deficiency were analyzed in isolated perfused and ventilated mouse lungs. Under basal conditions, the Ppa mean was unaffected by pharmacological broad-spectrum PKC inhibition with BIM (mean \pm SEM: $10.11 \pm 0.09 \mathrm{~cm} \mathrm{H}_{2} \mathrm{O}$ ) compared to solvent treatment $\left(10.23 \pm 0.12 \mathrm{~cm} \mathrm{H}_{2} \mathrm{O}\right)$, by selective inhibition of the conventional $\mathrm{PKC}$ isozymes PKC $\alpha$ and PKC $\beta$ with Gö6976 (10.51 $\left.\pm 0.16 \mathrm{~cm} \mathrm{H}_{2} \mathrm{O}\right)$ compared to solvent treatment $\left(10.30 \pm 0.15 \mathrm{~cm} \mathrm{H}_{2} \mathrm{O}\right)$ or by PKCa deficiency $\left(9.30 \pm 0.18 \mathrm{~cm} \mathrm{H}_{2} \mathrm{O}\right)$ compared to the WT control $\left(9.81 \pm 0.15 \mathrm{~cm} \mathrm{H}_{2} \mathrm{O}\right)$.

Pulmonary vascular responsiveness to the TP receptor agonist U46619 was reduced by trend following broadspectrum PKC inhibition when compared to solvent treatment (fig. 1a), suggesting a moderate role of PKC in thromboxane-evoked pulmonary vasoconstriction as shown before [26]. Selective cPKC inhibition had no effect on the U46619-evoked pressure response (fig. 1b), which is in line with previous findings [16]. Surprisingly, U46619induced pulmonary vascular responsiveness was highly increased in $\mathrm{PKCa}^{-/-}$lungs compared to the corresponding WT lungs (fig. 1c). This pulmonary vascular hyperre- c $\mathrm{PKCa}^{-/-}$mice showed a significantly greater increase in Ppa compared to the corresponding WT mice upon U46619 stimulation. Data represent the percentage of the pressure response observed in the respective control group at highest concentration. Values are shown as mean + SEM. $\mathbf{a} \mathrm{n}=11$ per group; $\mathbf{b}, \mathbf{c} \mathrm{n}=6-7$ per group. ${ }^{* *} \mathrm{p} \leq 0.01$ versus WT group. sponsiveness in $\mathrm{PKCa}^{-/-}$mice was, at first sight, contradictory, as $\mathrm{PKCa}$ is thought to promote vasoconstriction $[40,41]$. To analyze whether this hyperresponsiveness is (1) thromboxane-specific or (2) specific for vasoconstriction initiated at the vascular site via direct $G$ protein-coupled receptor activation, we studied pulmonary vascular responsiveness to ET-1 and serotonin as well as HPV.

\section{ET-1-Induced Pulmonary Vascular Responsiveness Is $P K C \alpha$-Dependent}

Both broad-spectrum PKC inhibition (fig. 2a) and the selective inhibition of the $\mathrm{CPKC}$ isozymes $\mathrm{PKC} a$ and $\mathrm{PKC} \beta$ (fig. 2b) reduced the pulmonary vasoconstriction induced by ET-1 application. Furthermore, pulmonary vascular responsiveness to ET-1 was markedly reduced by about $40 \%$ in $\mathrm{PKCa}^{-/}$mice compared to in WT mice (fig. 2c), suggesting that $\mathrm{PKCa}$ is the main PKC isozyme promoting the pulmonary vasopressor response to ET-1.

In contrast, serotonin-induced pulmonary vascular responsiveness was not altered by broad-spectrum PKC inhibition (fig. 3a) or PKCa deficiency (fig. 3b).

\section{HPV Is PKC-Dependent but Not PKC $\alpha$-Dependent}

Hypoxic ventilation led to the characteristic increase in Ppa mean. As shown before by Weissmann et al. [18], PKC inhibition distinctly reduced HPV (fig. 4a). Consistently, as revealed by the P-Q curves, PKC inhibition di- 


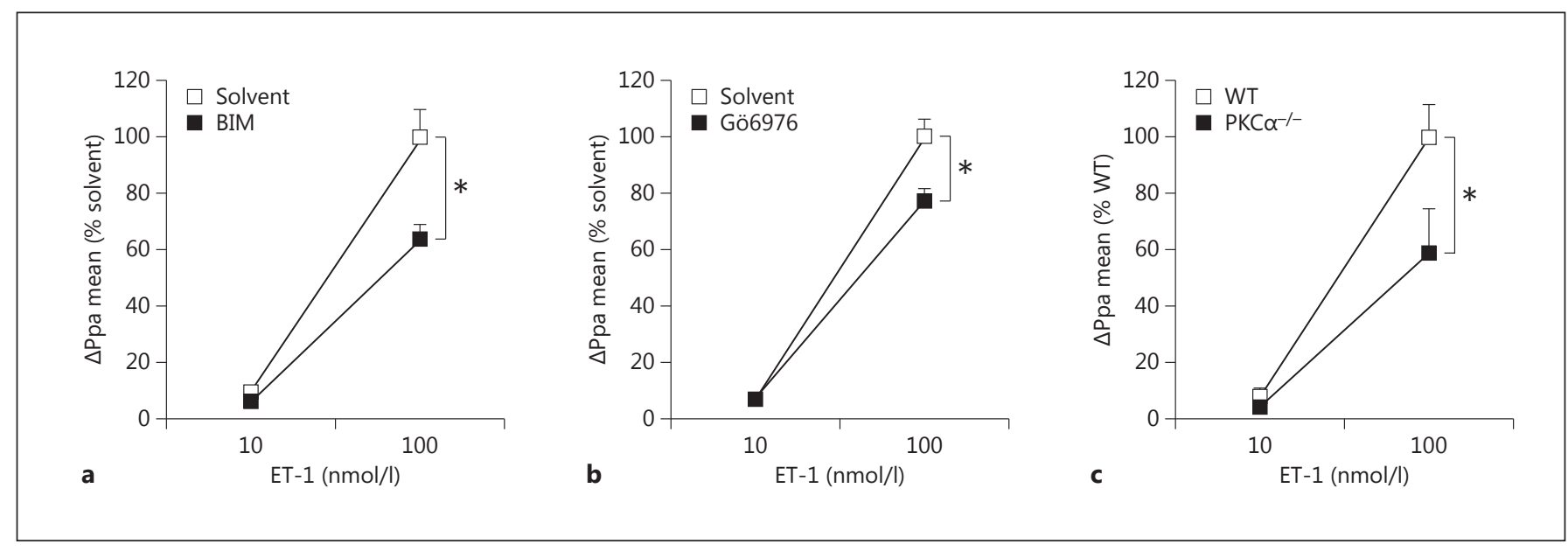

Fig. 2. PKCa is required for ET-1-induced pulmonary vasoconstriction. Broad-spectrum PKC inhibition (BIM; $1 \mu \mathrm{mol} / \mathrm{l} ; \mathbf{a}$ ), selective inhibition of conventional PKC isozymes (Gö6976; $1 \mu \mathrm{mol} / \mathrm{l}$; b) or PKCa deficiency (c) decreased the Ppa response towards ET-1 compared to the respective control group in isolated perfused mouse lungs. Data represent the percentage of the pressure response seen in the respective control group at highest concentration. Values are shown as mean + SEM. $n=4-7$ per group. $* \mathrm{p} \leq 0.05$ versus solvent or WT group.
Fig. 3. Serotonin-evoked pulmonary vasoconstriction does not involve PKCa. a Following PKC inhibitor application (BIM; $1 \mu \mathrm{mol} / \mathrm{l})$, pulmonary vascular responsiveness to serotonin was comparable to the vasopressor response observed in the solventtreated control group. b Similarly, PKCa deficiency had no effect on serotonin-induced pulmonary vasoconstriction. Data represent the percentage of the pressure response observed in the respective control group at highest concentration. Values are shown as mean+ SEM. $n=7-8$ per group.
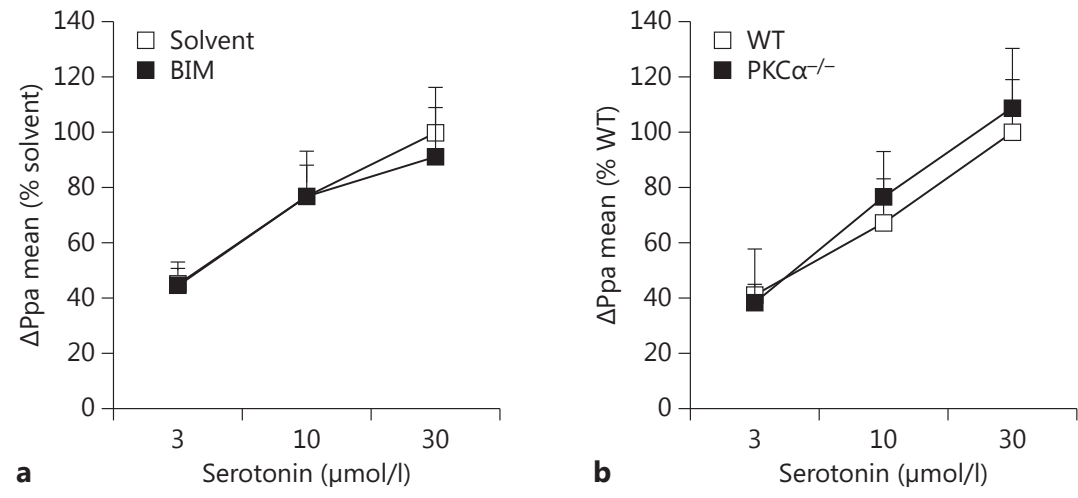

minished Ppa mean over the course of all 4 flow rates under hypoxia, whereas the flow-induced increase in Ppa mean was unaltered by PKC inhibition under normoxic conditions (fig. 4b). PKCa deficiency, however, did not affect HPV (fig. 4c) or P-Q curves (fig. 4d) when compared to WT mice.

Thus, the initially observed pulmonary hyperresponsiveness to $\mathrm{U} 46619$ in $\mathrm{PKCa}^{-/-}$mice was most likely thromboxane-specific. To elucidate the underlying mechanism of the U46619-evoked hyperresponsiveness, we performed quantitative mRNA analyses of the TP receptor and PKC isozymes.

PKCa and Pulmonary Vascular Responsiveness
mRNA Expression of TP Receptor and Atypical PKCı Is Upregulated in Microdissected Intrapulmonary Arteries from $\mathrm{PKC}^{-/-}$Mice

mRNA expression levels of the TP receptor and PKC isozymes were measured in laser-capture microdissected intrapulmonary arteries and whole-lung tissue homogenates from naïve $\mathrm{PKCa}^{-/-}$and WT mice. The rank order of $\mathrm{PKC}$ isozyme expression in the WT intrapulmonary arteries was as follows: $\mathrm{PKC} \delta>\mathrm{PKC} \varepsilon>\mathrm{PKC} \zeta>\mathrm{PKCI}>$ $\mathrm{PKC} \alpha>\mathrm{PKC} \eta>\mathrm{PKC} \beta>\mathrm{PKC} \theta>\mathrm{PKC} \gamma$ (online suppl. fig. 2). Notably, TP receptor mRNA expression in microdissected intrapulmonary arteries from $\mathrm{PKCa}^{-1-}$ mice 
Fig. 4. $\mathrm{HPV}$ requires $\mathrm{PKC}$, but not specifically PKCa. PKC inhibition (BIM; $1 \mu \mathrm{mol} / \mathrm{l})$ reduced $\operatorname{HPV}\left(1 \% \mathrm{O}_{2}\right)(\mathbf{a})$ and the flow (Q)-induced increase in Ppa under hypoxia (b) but not under normoxia. PKCa deficiency did not alter HPV (c) or pressure-flow curves (d). Data represent the percentage of the pressure response to hypoxic ventilation or the highest flow rate (Q) seen in the respective control group. Values are shown as mean + SEM. $\mathbf{a}, \mathbf{b} \mathbf{n}=$ 5 per group; $\mathbf{c}, \mathbf{d} \mathrm{n}=8-9$ per group. ${ }^{* *} \mathrm{p} \leq$ $0.01{ }^{* * *} \mathrm{p} \leq 0.001$ versus solvent group.
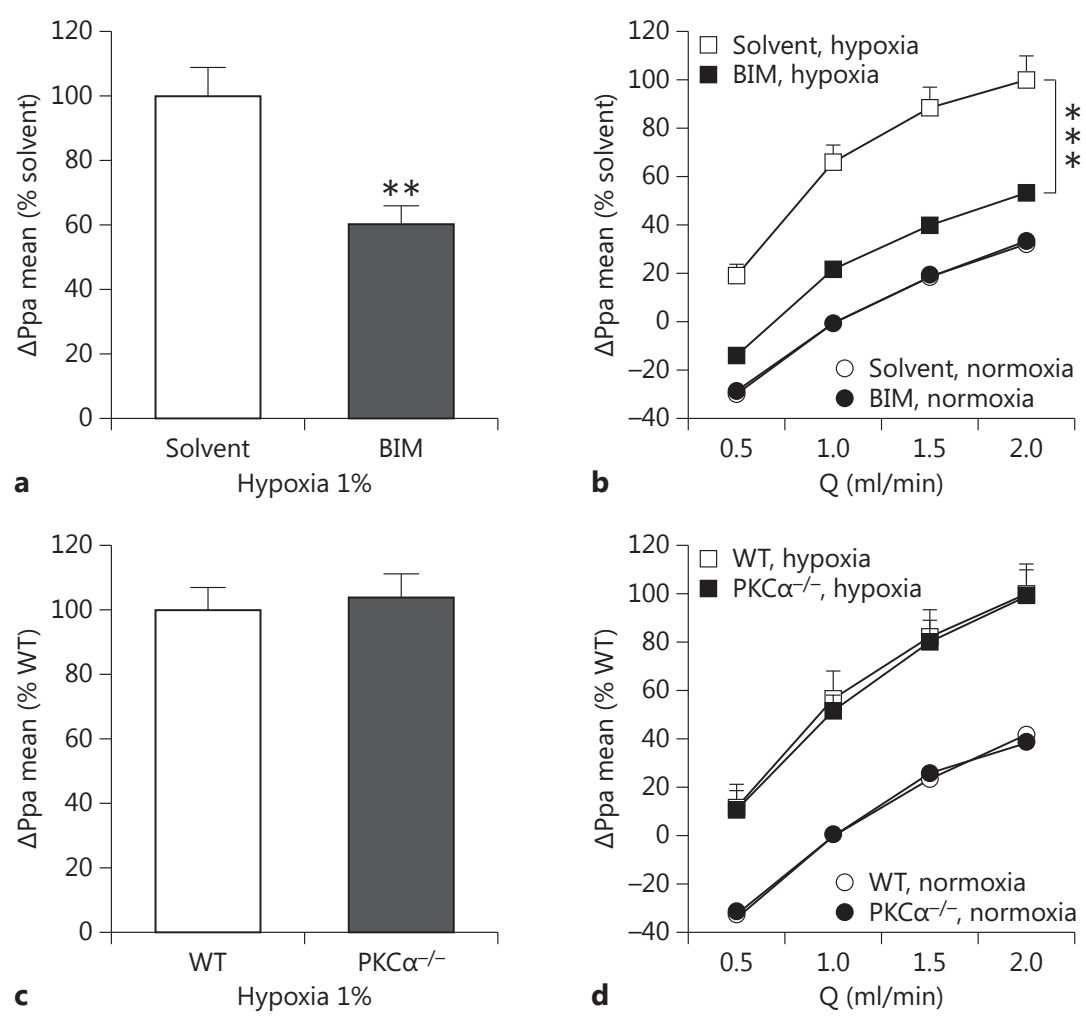

Fig. 5. PKCa deficiency leads to increased $\mathrm{TP}$ receptor and PKCi mRNA expression in intrapulmonary arteries. a, b mRNA expression analysis from microdissected intrapulmonary arteries showed a 2.7-fold increase in the expression of $\mathrm{TP}$ receptor and $\mathrm{PKC} \mathrm{mRNA}$ in $\mathrm{PKCa}^{-/-}$compared to in WT pulmonary arteries. Data represent the relative quantitative gene expression: mRNA expression levels were normalized to GAPDH levels and compared to expression levels in WT mice using the comparative Ct method. Values are shown as mean + SEM. $\mathrm{n}=5-7$ per group. ${ }^{*} \mathrm{p} \leq 0.05$; ** $\mathrm{p} \leq 0.01$ versus WT group.

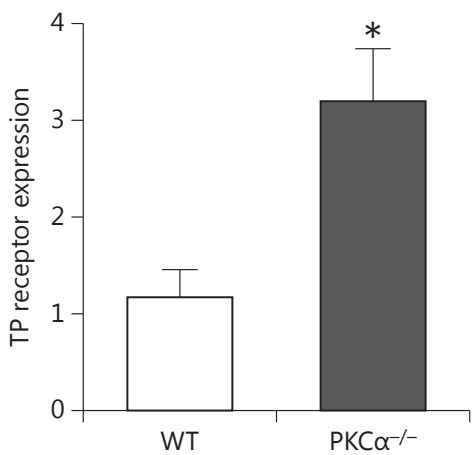

a

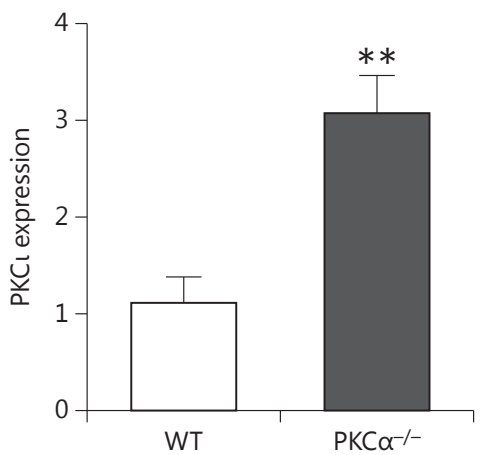

b was 2.7-fold greater compared to WT mice (fig. 5a). Similarly, PKCı mRNA levels were highly elevated in the intrapulmonary arteries from $\mathrm{PKCa}^{-/-}$mice (2.7-fold; fig. 5b).

In contrast, mRNA expression levels of conventional isozymes $\mathrm{PKC} \beta$ and $\mathrm{PKC} \gamma$, novel isozymes $\mathrm{PKC} \delta, \mathrm{PKC} \varepsilon$, $\mathrm{PKC} \eta \mathrm{PKC} \theta$ and the atypical isozyme $\mathrm{PKC} \zeta$ were similar in the intrapulmonary arteries of $\mathrm{PKCa}^{-/-}$and WT mice (online suppl. table 1).

The elevated expression of TP receptor and $\mathrm{PKC}$ in PKCa-deficient lungs seems to be specific to the pulmonary arteries, since no differential expression of $\mathrm{TP}$ receptor and $\mathrm{PKC}$ isozyme in whole-lung tissue homogenates was detected between $\mathrm{PKCa}^{-/-}$and WT mice (data not shown). 
Elevated PKCı Expression in PKC $\alpha^{-/-}$Pulmonary

Arteries Does Not Contribute to Vascular

Hyperresponsiveness to U46619 in PKC $\alpha^{-/-}$Lungs

As revealed by mRNA analysis, increased TP receptor expression possibly leads to pulmonary vascular hyperresponsiveness to U46619 in $\mathrm{PKCa}^{-/-}$mice. However, since $\mathrm{PKCl}$ has been shown to mediate contraction of the rat corpus cavernosum [42], a contribution by $\mathrm{PKC}$ to the vascular hyperresponsiveness that we observed also seems possible. To elucidate the functional role of upregulated PKCı in the vasculature of $\mathrm{PKCa}^{-/-}$lungs, the effect of PKCı inhibitor ATM on U46619-evoked pulmonary vasoconstriction was assessed. Basal Ppa mean was unaffected by $\mathrm{PKC} \mathrm{inhibition}$ (mean \pm SEM: $9.64 \pm 0.23$ $\mathrm{cm} \mathrm{H}_{2} \mathrm{O}$ ) compared to the solvent treatment $(9.36 \pm 0.33$ $\mathrm{cm} \mathrm{H}_{2} \mathrm{O}$ ). Importantly, $\mathrm{PKC}$ inhibition did not reduce pulmonary vascular hyperresponsiveness to U46619 in $\mathrm{PKCa}^{-/-}$mice (fig. 6), allowing us to conclude that besides elevated TP receptor expression in intrapulmonary arteries, increased PKCı expression is most likely not causative for this increased vasopressor response.

\section{Discussion}

This study demonstrates PKC isozyme-specific functions in the pulmonary vasculature. PKCa contributed to pulmonary vasoconstriction induced by ET-1. Conversely, however, PKCa deficiency led to pulmonary vascular hyperresponsiveness to TXA2, possibly via the upregulation of the TP receptor in the intrapulmonary arteries. Furthermore, HPV, although diminished following PKC inhibition, did not depend on the isozyme, $\mathrm{PKC}$, whereas serotonin-induced pulmonary vasoconstriction was unaffected by both PKC inhibition or PKCa deficiency.

ET-1-evoked pulmonary vasoconstriction was reduced by approximately $40 \%$ in $\mathrm{PKC} \alpha$-deficient mice compared to WT mice, suggesting a prominent role for the PKC isozyme, $\mathrm{PKCa}$, in the pulmonary vasopressor response to ET-1. These findings are consistent with a study by Feng et al. [41] demonstrating a significant role for PKCa signaling in ET-1-induced coronary microvascular vasoconstriction. Moreover, ET-1-induced contraction of isolated mesenteric arteries was reduced following treatment with a PKCa inhibitor peptide [43]. Interestingly, in a study by Weigand et al. [44], ET-1-induced contraction in pulmonary arteries from chronically hypoxic rats was shown to be unaffected by $\mathrm{PKC}$ inhibition, possibly pointing to altered mechanisms of ET-1-induced contraction under hypoxic conditions, which require further investigations. In

PKCa and Pulmonary Vascular

Responsiveness

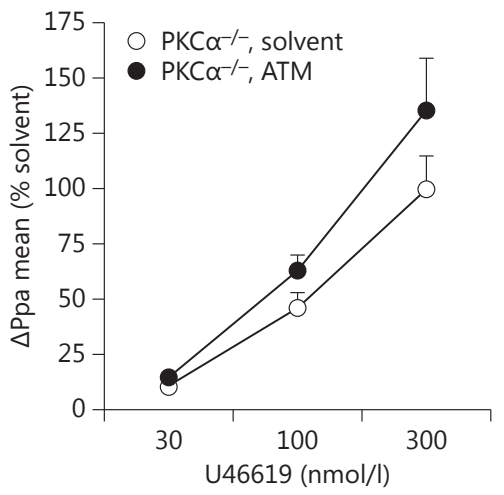

Fig. 6. $\mathrm{PKCl}$ inhibition does not reduce vascular hyperresponsiveness to $\mathrm{U} 46619$ in $\mathrm{PKCa}^{-/-}$lungs. Following application of $\mathrm{PKCl}$ inhibitor ATM $(20 \mu \mathrm{mol} / \mathrm{l})$, pulmonary vasoconstriction induced by TP receptor agonist $\mathrm{U} 46619$ was unaltered $(\mathrm{p}=0.17)$ compared to solvent treatment. Data represent the percentage of the pressure response seen in the respective control group at highest concentration. Values are shown as mean $+\mathrm{SEM} ; \mathrm{n}=7$ per group.

contrast to the vasopressor response to ET-1, isozyme PKCa did not contribute to HPV, which has previously been shown to depend on PKC [18-20] and particularly isozyme PKCe [17], again indicating isozyme-specific functions in the pulmonary vasculature.

Surprisingly, PKCa deficiency led to pulmonary vascular hyperresponsiveness to the TXA2 analog U46619. As $\mathrm{PKCa}$ is proposed to be a promoter of smooth muscle cell contraction $[40,41,43]$, this finding was unexpected. TXA2 is a prostanoid derived from arachidonic acid, which exerts its constrictive effects by binding TP receptors on vascular smooth muscle cells, leading to the inhibition of voltage-gated $\mathrm{K}^{+}$channels, membrane depolarization, the activation of L-type $\mathrm{Ca}^{2+}$ channels, and ultimately smooth muscle cell contraction [16]. The thromboxane system has been implicated in the pathogenesis of $\mathrm{PAH}[2,45]$. In this study, we observed that the pulmonary vascular hyperresponsiveness to U46619 in isolated $\mathrm{PKC}^{-/-}$lungs coincided with pulmonary arterial TP receptor upregulation. Although it is tempting to speculate that compensatory $\mathrm{TP}$ receptor upregulation is a result of constitutive $\mathrm{PKC} \alpha$ deficiency in $\mathrm{PKC} \alpha^{-/-}$mice, the exact underlying mechanisms leading to this upregulation in PKCa deficiency remain elusive. Also, the pathophysiological impact of this observation is unclear. However, since neither broad-spectrum PKC inhibition nor selective $\mathrm{CPKC}$ inhibition led to an increased pulmonary vaso- 
pressor response to U46619, the hyperresponsiveness in $\mathrm{PKCa}^{-/-}$lungs that we observed seems to rather be a result of TP receptor upregulation in the intrapulmonary arteries than a direct effect of the absence of PKCa.

To our knowledge, there are no published data on PKCa expression in PAH patients. A study by Shi et al. [46] demonstrated decreased PKCa expression in the pulmonary arteries of rats with hypoxia-induced pulmonary hypertension. Moreover, increased TP receptor density has been observed in the right ventricular tissue of PAH patients [47].

Besides TP receptor expression, $\mathrm{PKC}$ expression was shown to be elevated in the intrapulmonary arteries of $\mathrm{PKCa}^{-1-}$ mice. However, the role of $\mathrm{PKCl}$ in pulmonary vasoconstriction is currently unknown. A large body of literature has discussed $\mathrm{PKCl}$ as a tumor oncogene [48], but very little is known about its role in adult pulmonary vasculature. $\mathrm{PKCl}$ activation during embryonic vasculogenesis [49] and a potential role for PKCa and PKCı in phenylephrine-induced contraction of the rat corpus cavernosum have been proposed [42]. However, compensative modulation of pulmonary vascular function by $\mathrm{PKC} \mathrm{I}$ in $\mathrm{PKCa}^{-/-}$mice is unlikely, since pulmonary vascular hyperresponsiveness to U46619 was not reduced in $\mathrm{PKC}^{-/-}$lungs following $\mathrm{PKCl}$ inhibition, as shown in this study. In line with this notion, it has been reported that treatment with the $\mathrm{PKCl}$ inhibitor sodium aurothiomalate failed to inhibit adrenaline-induced constriction of rat anterior mesenteric artery and vein [50] as well as epidermal growth factor-urogastrone-evoked contraction in isolated longitudinal smooth muscle strips from guinea-pig stomach [51]. Nevertheless, to our knowledge, this is the first report on the effects of selective PKCl inhibition on pulmonary vasoconstriction focusing on the specific response to $\mathrm{U} 46619$ in $\mathrm{PKCa}^{-/-}$lungs, so a potential PKCl-mediated modulation of pulmonary vascular function needs to be further evaluated in future studies.

Remarkably, serotonin-induced pulmonary vasoconstriction was not altered by the PKC inhibitor BIM $(1 \mu \mathrm{mol} / \mathrm{l})$ or PKCa deficiency in isolated perfused naïve mouse lungs. This is consistent to some extent with the report by Kaye et al. [27], showing that the feline pulmonary vasoconstrictor response to serotonin was unaffected by pretreatment with the PKC inhibitor staurosporine or calphostin C. Nevertheless, in the same study, staurosporine was observed to diminish the pulmonary arterial pressor response to serotonin in isolated perfused rat lungs [27]. BIM $(10 \mu \mathrm{mol} / \mathrm{l})$ also reduced the hyperresponsive vasoconstriction towards serotonin in isolated perfused lungs of ovalbumin-sensitized and ovalbumin- challenged mice [9]. In addition, the PKC inhibitors Gö6976 and staurosporine have been shown to reduce serotonin-evoked reactivity of rat PASMCs [28] or the pulmonary vasculature in isolated canine lungs [29], respectively. However, staurosporine is the precursor of BIM and, with a relatively high affinity to other protein kinases, it is less PKC-specific than BIM [52]. Gö6976 is a selective inhibitor of conventional PKC $\alpha$ and PKC $\beta$.

Our data suggest that serotonin-evoked pulmonary vasoconstriction is not mediated via PKC, and particularly not via PKCa in isolated naïve mouse lungs. Several explanations for the seemingly contradictory findings are possible, including species specificity, differences in the complexity of models or the varying isozyme selectivity profiles of different PKC inhibitors, particularly when applied at different concentrations. Since the BIM-evoked half maximal inhibition $\left(\mathrm{IC}_{50}\right)$ for relevant conventional and novel $\mathrm{PKC}$ isozymes ranges roughly from 8 to $210 \mathrm{nmol} / \mathrm{l}$ (according to the manufacturer), the currently employed concentration of $1 \mu \mathrm{mol} / \mathrm{l} \mathrm{BIM}$ indicates an adequate $\mathrm{cPKC} /$ $\mathrm{nPKC}$ inhibition under physiological conditions, and is the preferred working concentration for vasoconstriction analysis in naïve isolated perfused lungs $[53,54]$. On the other hand, $\mathrm{IC}_{50}$ for atypical PKC $\zeta$ requires $5.8 \mu \mathrm{mol} / \mathrm{l}$ of BIM. Thus, the somewhat weak reduction of U46619-induced vasoconstriction that we observed can possibly be explained by only a partial inhibition of $\mathrm{PKC} \zeta$, as $\mathrm{PKC} \zeta$ has been shown to promote U46619-evoked pulmonary vasoconstriction [16]. Moreover, as we could not entirely rule out PKCı-mediated pulmonary vasoconstriction, the weak or failed reduction of the vasopressor responses to U46619 and serotonin, respectively, by BIM, may also be in part explained by the fact that $\mathrm{PKCl}$ was probably not affected or was incompletely affected by $1 \mu \mathrm{mol} / \mathrm{l}$ of BIM.

In summary, we identified the PKC family as important agonist-specific modulators of pulmonary vascular function. HPV was affected by broad-spectrum PKC inhibition, but not by a deficiency of the PKCa isozyme. In contrast, the ET-1-evoked pulmonary vasoconstriction, which is assumed to be an important feature of $\mathrm{PAH}$ pathophysiology, was promoted by PKCa. However, PKCa deficiency led to pulmonary vascular hyperresponsiveness towards TXA2, which coincided with increased TP receptor expression. This finding may be of clinical relevance and should be kept in mind when discussing PKC isozymes and, in particular, $\mathrm{PKCa}$, as potential targets for $\mathrm{PAH}$ therapy. Further studies are warranted to analyze whether the pharmacological, long-term inhibition of PKCa counteracts its possible beneficial effects on the pulmonary vasculature by TP receptor upregulation. 


\section{Acknowledgements}

This project was supported in part by the German Research Foundation (SFB-TR84 C2 and C5 to S.H., B1 and Z2 to N.S., C3 and C6 to M.W.). The authors would like to thank Monika Schaerig and Denise Barthel for excellent technical assistance, Wolfgang M. Kuebler for thoughtful discussions, Michael Leitges for providing $\mathrm{PKCa}^{-/-}$mice and Jasmin Lienau for proof-reading of the manuscript.

\section{Disclosure Statement}

None of the authors have competing interests.

\section{References}

1 Morrell NW, Adnot S, Archer SL, Dupuis J, Jones PL, MacLean MR, McMurtry IF, Stenmark KR, Thistlethwaite PA, Weissmann N, Yuan JX, Weir EK: Cellular and molecular basis of pulmonary arterial hypertension. J Am Coll Cardiol 2009;54:S20-S31.

2 Christman BW, McPherson CD, Newman JH, King GA, Bernard GR, Groves BM, Loyd JE: An imbalance between the excretion of thromboxane and prostacyclin metabolites in pulmonary hypertension. N Engl J Med 1992; 327:70-75.

3 Giaid A, Yanagisawa M, Langleben D, Michel RP, Levy R, Shennib H, Kimura S, Masaki T, Duguid WP, Stewart DJ: Expression of endothelin-1 in the lungs of patients with pulmonary hypertension. N Engl J Med 1993;328: 1732-1739.

4 Herve P, Launay JM, Scrobohaci ML, Brenot F, Simonneau G, Petitpretz P, Poubeau P, Cerrina J, Duroux P, Drouet L: Increased plasma serotonin in primary pulmonary hypertension. Am J Med 1995;99:249-254.

5 Cremona G, Higenbottam T, Borland C, Mist B: Mixed expired nitric oxide in primary pulmonary hypertension in relation to lung diffusion capacity. QJM 1994;87:547-551.

6 Brink C, Cerrina C, Labat C, Verley J, Benveniste J: The effect of contractile agonists on isolated pulmonary arterial and venous muscle preparations derived from patients with primary pulmonary hypertension. Am Rev Resp Dis 1988;137.

7 Becker MO, Kill A, Kutsche M, Guenther J, Rose A, Tabeling C, Witzenrath M, Kuhl AA, Heidecke H, Ghofrani HA, Tiede H, Schermuly RT, Nickel N, Hoeper MM, Lukitsch I, Gollasch M, Kuebler WM, Bock S, Burmester GR, Dragun D, Riemekasten G: Vascular receptor autoantibodies in pulmonary arterial hypertension associated with systemic sclerosis. Am J Respir Crit Care Med 2014;190:808817.

8 Gillespie MN, Olson JW, Reinsel CN, O'Connor WN, Altiere RJ: Vascular hyperresponsiveness in perfused lungs from monocrotaline-treated rats. Am J Physiol 1986; 251:H109-H114.
9 Witzenrath M, Ahrens B, Kube SM, Hocke AC, Rosseau S, Hamelmann E, Suttorp N, Schutte H: Allergic lung inflammation induces pulmonary vascular hyperresponsiveness. Eur Respir J 2006;28:370-377.

10 Haberberger RV, Tabeling C, Runciman S, Gutbier B, Konig P, Andratsch M, Schutte H, Suttorp N, Gibbins I, Witzenrath M: Role of sphingosine kinase 1 in allergen-induced pulmonary vascular remodeling and hyperresponsiveness. J Allergy Clin Immunol 2009; 124:933-941.e931-e939.

11 Delannoy E, Courtois A, Freund-Michel V, Leblais V, Marthan R, Muller B: Hypoxia-induced hyperreactivity of pulmonary arteries: role of cyclooxygenase-2, isoprostanes, and thromboxane receptors. Cardiovasc Res 2010; 85:582-592.

12 Dempsey EC, Newton AC, Mochly-Rosen D, Fields AP, Reyland ME, Insel PA, Messing RO: Protein kinase $\mathrm{C}$ isozymes and the regulation of diverse cell responses. Am J Physiol Lung Cell Mol Physiol 2000;279:L429-L438.

13 Ward JP, Knock GA, Snetkov VA, Aaronson PI: Protein kinases in vascular smooth muscle tone-role in the pulmonary vasculature and hypoxic pulmonary vasoconstriction. Pharmacol Ther 2004;104:207-231.

14 Cogolludo A, Moreno L, Villamor E: Mechanisms controlling vascular tone in pulmonary arterial hypertension: implications for vasodilator therapy. Pharmacology 2007;79:6575 .

15 Chen L, Hahn H, Wu G, Chen CH, Liron T, Schechtman D, Cavallaro G, Banci L, Guo Y, Bolli R, Dorn GW 2nd, Mochly-Rosen D: Opposing cardioprotective actions and parallel hypertrophic effects of delta PKC and epsilon PKC. Proc Natl Acad Sci USA 2001;98: 11114-11119.

16 Cogolludo A, Moreno L, Bosca L, Tamargo J, Perez-Vizcaino F: Thromboxane A2-induced inhibition of voltage-gated $\mathrm{K}+$ channels and pulmonary vasoconstriction: role of protein kinase Czeta. Circ Res 2003;93:656-663.

17 Littler CM, Morris KG Jr, Fagan KA, McMurtry IF, Messing RO, Dempsey EC: Protein kinase $\mathrm{C}$-epsilon-null mice have decreased hypoxic pulmonary vasoconstriction. Am J Physiol Heart Circ Physiol 2003;284:H1321H1331.
18 Weissmann N, Voswinckel R, Hardebusch T, Rosseau S, Ghofrani HA, Schermuly R, Seeger W, Grimminger F: Evidence for a role of protein kinase $\mathrm{C}$ in hypoxic pulmonary vasoconstriction. Am J Physiol 1999;276:L90-L95.

19 Tsai BM, Wang M, Pitcher JM, Meldrum KK, Meldrum DR: Hypoxic pulmonary vasoconstriction and pulmonary artery tissue cytokine expression are mediated by protein kinase C. Am J Physiol Lung Cell Mol Physiol 2004;287:L1215-L1219.

20 Tsai BM, Patel K, Wang M, Morrell ED, Crisostomo PR, Meldrum DR: Selective protein kinase $\mathrm{C}$ inhibition attenuates pulmonary artery cytokine expression without affecting hypoxic pulmonary vasoconstriction. Shock 2007;27:36-39.

21 Snow JB, Gonzalez Bosc LV, Kanagy NL, Walker BR, Resta TC: Role for PKCbeta in enhanced endothelin-1-induced pulmonary vasoconstrictor reactivity following intermittent hypoxia. Am J Physiol Lung Cell Mol Physiol 2011;301:L745-L754.

22 Damron DS, Nadim HS, Hong SJ, Darvish A, Murray PA: Intracellular translocation of $\mathrm{PKC}$ isoforms in canine pulmonary artery smooth muscle cells by ANG II. Am J Physiol 1998;274:L278-L288.

23 Shimoda LA, Sylvester JT, Booth GM, Shimoda TH, Meeker S, Undem BJ, Sham JS: Inhibition of voltage-gated $\mathrm{K}(+)$ currents by endothelin-1 in human pulmonary arterial myocytes. Am J Physiol Lung Cell Mol Physiol 2001;281:L1115-L1122.

24 Sylvester JT, Shimoda LA, Aaronson PI Ward JP: Hypoxic pulmonary vasoconstriction. Physiol Rev 2012;92:367-520.

25 Wang L, Yin J, Nickles HT, Ranke H, Tabuchi A, Hoffmann J, Tabeling C, Barbosa-Sicard E, Chanson M, Kwak BR, Shin HS, Wu S, Isakson BE, Witzenrath M, de Wit C, Fleming I, Kuppe H, Kuebler WM: Hypoxic pulmonary vasoconstriction requires connexin 40-mediated endothelial signal conduction. J Clin Invest 2012;122:4218-4230.

26 Murtha YM, Allen BM, Orr JA: The role of protein kinase $\mathrm{C}$ in thromboxane $\mathrm{A} 2$-induced pulmonary artery vasoconstriction. J Biomed Sci 1999;6:293-295.
PKCa and Pulmonary Vascular Responsiveness
J Vasc Res 2015;52:279-288

DOI: $10.1159 / 000443402$ 
27 Kaye AD, Nossaman BD, Ibrahim IN, Feng CJ, Kadowitz PJ: Influence of protein kinase $\mathrm{C}$ inhibitors on vasoconstrictor responses in the pulmonary vascular bed of cat and rat. Am J Physiol 1995;268:L532-L538.

28 Cogolludo A, Moreno L, Lodi F, Frazziano G, Cobeno L, Tamargo J, Perez-Vizcaino F: Serotonin inhibits voltage-gated $\mathrm{K}+$ currents in pulmonary artery smooth muscle cells: role of 5-HT2A receptors, caveolin-1, and KV1.5 channel internalization. Circ Res 2006;98: 931-938.

29 Barman SA, Pauly JR, Isales CM: Canine pulmonary vasoreactivity to serotonin: role of protein kinase $\mathrm{C}$ and tyrosine kinase. Am J Physiol 1997;272:H740-H747.

30 Leitges M, Plomann M, Standaert ML, Bandyopadhyay G, Sajan MP, Kanoh Y, Farese $\mathrm{RV}$ : Knockout of PKC alpha enhances insulin signaling through PI3K. Mol Endocrinol 2002;16:847-858

31 Held HD, Martin C, Uhlig S: Characterization of airway and vascular responses in murine lungs. Br J Pharmacol 1999;126:1191-1199.

32 Tabeling C, Scheer H, Schonrock SM, Runge F, Gutbier B, Lienau J, Hamelmann E, Opitz B, Suttorp N, Mayer K, Behrens GM, Tschernig $T$, Witzenrath M: Nucleotide oligomerization domain 1 ligation suppressed murine allergen-specific T-cell proliferation and airway hyperresponsiveness. Am J Respir Cell Mol Biol 2014;50:903-911.

33 Heine G, Tabeling C, Hartmann B, Gonzalez Calera CR, Kühl AA, Lindner J, Radbruch A, Witzenrath M, Worm M: 25-hydroxvitamin D3 promotes the long-term effect of specific immunotherapy in a murine allergy model. J Immunol 2014;193:1017-1023.

34 Schulze T, Golfier S, Tabeling C, Rabel K, Gräler MH, Witzenrath M, Lipp M: Sphingosine-1-phosphate receptor $4\left(\mathrm{~S} \mathrm{P}_{4}\right)$ deficiency profoundly affects dendritic cell function and TH17-cell differentiation in a murine model. FASEB J 2011;25:4024-4036.

35 Heimburger M, Lerner R, Palmblad J: Effects of antirheumatic drugs on adhesiveness of endothelial cells and neutrophils. Biochem Pharmacol 1998;56:1661-1669.

36 Oba T, Ishikawa T, Yamaguchi M: Different effects of two gold compounds on muscle contraction, membrane potential and ryano- dine receptor. Eur J Pharmacol 1999;374: 477-487.

37 Tabeling C, Yu H, Wang L, Ranke H, Goldenberg NM, Zabini D, Noe E, Krauszman A, Gutbier B, Yin J, Schaefer M, Arenz C, Hocke AC, Suttorp N, Proia RL, Witzenrath M, Kuebler WM: CFTR and sphingolipids mediate hypoxic pulmonary vasoconstriction. Proc Natl Acad Sci USA 2015; 112:E1614-E1623.

38 Spöhr F, Busch CJ, Reich C, Motsch J, Gebhard MM, Kuebler WM, Bloch KD, Weimann $\mathrm{J}$ : 4-Aminopyridine restores impaired hypoxic pulmonary vasoconstriction in endotoxemic mice. Anesthesiology 2007; 107:597604.

39 Spöhr F, Cornelissen AJ, Busch C, Gebhard MM, Motsch J, Martin EO, Weimann J: Role of endogenous nitric oxide in endotoxin-induced alteration of hypoxic pulmonary vasoconstriction in mice. Am J Physiol Heart Circ Physiol 2005;289:H823-H831.

40 Dallas A, Khalil RA: Ca2+ antagonist-insensitive coronary smooth muscle contraction involves activation of epsilon-protein kinase C-dependent pathway. Am J Physiol Cell Physiol 2003;285:C1454-C1463.

41 Feng J, Liu Y, Khabbaz KR, Hagberg R, Sodha NR, Osipov RM, Sellke FW: Endothelin-1-induced contractile responses of human coronary arterioles via endothelin-A receptors and PKC-alpha signaling pathways. Surgery 2010;147:798-804.

42 Husain S, Young D, Wingard CJ: Role of PKCalpha and PKCiota in phenylephrine-induced contraction of rat corpora cavernosa. Int J Impot Res 2004;16:325-333.

43 Rainbow RD, Norman RI, Everitt DE, Brignell JL, Davies NW, Standen NB: EndothelinI and angiotensin II inhibit arterial voltagegated $\mathrm{K}+$ channels through different protein kinase C isoenzymes. Cardiovasc Res 2009;83: 493-500.

44 Weigand L, Sylvester JT, Shimoda LA: Mechanisms of endothelin-1-induced contraction in pulmonary arteries from chronically hypoxic rats. Am J Physiol Lung Cell Mol Physiol 2006;290:L284-L290.

45 Hirenallur SD, Detweiler ND, Haworth ST, Leming JT, Gordon JB, Rusch NJ: Furegrelate, a thromboxane synthase inhibitor, blunts the development of pulmonary arterial hypertension in neonatal piglets. Pulm Circ 2012;2: 193-200.

46 Shi Y, Wang C, Han S, Pang B, Zhang N, Wang J, Li J: Determination of PKC isoformspecific protein expression in pulmonary arteries of rats with chronic hypoxia-induced pulmonary hypertension. Med Sci Monit 2012;18:BR69-BR75.

47 Katugampola SD, Davenport AP: Thromboxane receptor density is increased in human cardiovascular disease with evidence for inhibition at therapeutic concentrations by the AT(1) receptor antagonist losartan. Br J Pharmacol 2001;134:1385-1392.

48 Parker PJ, Justilien V, Riou P, Linch M, Fields AP: Atypical protein kinase Ciota as a human oncogene and therapeutic target. Biochem Pharmacol 2014;88:1-11.

49 Qi Y, Liu J, Wu X, Brakebusch C, Leitges M, Han Y, Corbett SA, Lowry SF, Graham AM, Li S: Cdc42 controls vascular network assembly through protein kinase Ciota during embryonic vasculogenesis. Arterioscler Thromb Vasc Biol 2011;31:1861-1870.

50 Northover BJ: The effect of anti-inflammatory drugs on vascular smooth muscle. $\mathrm{Br}$ Pharmacol Chemother 1967;31:483-493.

51 Itoh H, Muramatsu I, Patel P, Lederis K, Hollenberg MD: Inhibition by anti-inflammatory agents of contraction induced by epidermal growth factor-urogastrone in isolated longitudinal smooth muscle strips from guinea-pig stomach. Br J Pharmacol 1988;95:821-829.

52 Toullec D, Pianetti P, Coste H, Bellevergue P, Grand-Perret T, Ajakane M, Baudet V, Bois$\sin$ P, Boursier E, Loriolle F, et al: The bisindolylmaleimide GF 109203X is a potent and selective inhibitor of protein kinase C. J Biol Chem 1991;266:15771-15781.

53 Hammerschmidt S, Vogel T, Jockel S, Gessner C, Seyfarth HJ, Gillissen A, Wirtz H: Protein kinase $\mathrm{C}$ inhibition attenuates hypochloriteinduced acute lung injury. Respir Med 2007; 101:1205-1211.

54 Schermuly RT, Pullamsetti SS, Breitenbach SC, Weissmann N, Ghofrani HA, Grimminger F, Nilius SM, Schror K, Kirchrath JM, Seeger W, Rose F: Iloprost-induced desensitization of the prostacyclin receptor in isolated rabbit lungs. Respir Res 2007;8:4 